\title{
Biogeochemical interactions between iron and nutrient cycling in a saline inland lake
}

ROSANNA MARGALEF MARTI ${ }^{1}$, MATHIEU SEBILO ${ }^{1,2}$, AUBIN THIBAULT DE CHANVALON ${ }^{1}$, IVAN GONZALEZ ALVAREZ $^{1}$, CAMILLE MAZIÈRE ${ }^{1,3}$, MAXIMILIEN GUIBERT $^{1}$, EMMANUEL TESSIER $^{1}$, BÉATRICE LAUGA ${ }^{1}$ AND DAVID AMOUROUX ${ }^{4}$

${ }^{1}$ Université de Pau et des Pays de l'Adour, E2S UPPA, CNRS, IPREM

${ }^{2}$ Sorbonne Université, CNRS, IEES

${ }^{3}$ La Rochelle Université, UMR 7266 LIENSs, CNRS

${ }^{4}$ CNRS, Université de Pau et Pays de l'Adour, E2S UPPA, IPREM

Presenting Author: rosanna.margalef-marti@univ-pau.fr

In inland wetlands, variations of physical parameters such as salinity and $\mathrm{pH}$ are dependent to evaporation, rainfall or groundwater inflows and directly impact biogeochemical cycles. The interactions between these cycles can also present variations considering diurnal and seasonal time scales as response to changes in microbial activity. In order to study the associated modification of carbon, nitrogen, sulfur and iron cycling, a first sampling campaign was performed in the inland, saline and alkaline Gallocanta Lake (NE Spain) in November 2020. Superficial water, porewater and sediment samples were collected during a diurnal cycle in two distinct sites and analyzed for concentration, speciation and isotopic signature of nutrients, major and trace elements.

Preliminary results confirmed the appropriateness of Gallocanta Lake to study iron and nutrient cycling in saline aquatic environments. Measured conductivity in superficial water reached $20 \mathrm{mS} / \mathrm{cm}$ with $\mathrm{pH}$ up to 10 . Sulfur and iron cycling seem dominated by gypsum precipitation during groundwater cooling few centimeters below sediment surface and subsequent bacterial sulphate reduction in anoxic porewater. Indeed, $\mathrm{H}_{2} \mathrm{~S}$ flux was observed across the sediment water interface by microelectrode, likely due to activity of anoxygenic photosynthetic bacteria. A decrease in ammonium concentration in porewater was also observed from bottom $(13 \mathrm{~cm})$ to the surface of sediment, highlighting the occurrence of redox reactions involving iron, sulfur, carbon and nitrogen compounds. Isotope data allowed to confirm the interaction between different cycles.

Future sampling campaigns will be carried on aiming to check daily and seasonal variability on the main biogeochemical processes taking place in the lake. 